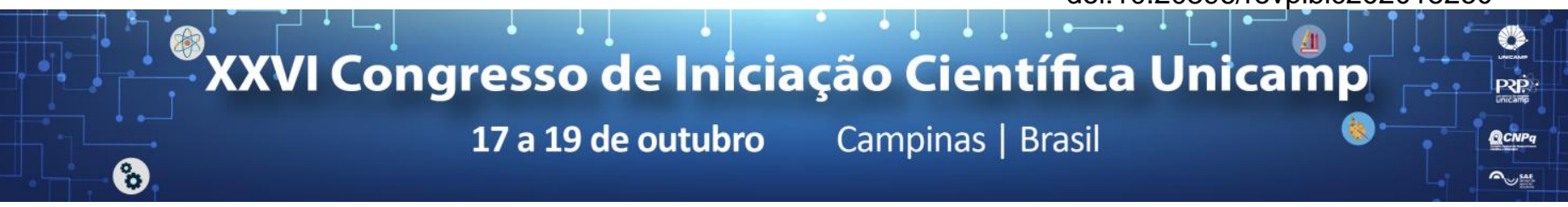

\title{
EXTRAÇÃO E CARACTERIZAÇÃO DO ÓLEO DA CASTANHA DE BARU (Dypterix alata)
}

\section{Bruna S. Santos, Júlia C. Coco, Janaína A. Ataide, Louise L. Tundisi, Priscila G. Mazzola, Elias B. Tambourgi}

\section{Resumo}

Diferentes métodos extrativos foram utilizados para a obtenção de extratos de castanha de baru, que foram caracterizados quanto a concentração de antocianinas e de fenóis totais, comparando com um óleo comercial. Em seguida, a estabilidade dos extratos foi estudada por 90 dias.

\section{Palavras-chave:}

Baru, Extração, Antioxidante

\section{Introdução}

A composição da castanha de baru (Dypterix alata) é marcada pelo alto grau de óleos insaturados ${ }^{1}$, com predominância dos ácidos oleico e linoleico, que são considerados ácidos graxos essenciais e podem alterar propriedades físicas das membranas, como fluidez, estabilidade e suscetibilidade ao dano oxidativo ${ }^{2}$. A castanha de baru foi então submetida a processos extrativos e posterior caracterização desses extratos, com o objetivo de encontrar o método mais efetivo. Neste trabalho, foram utilizados os métodos de Soxhlet e Maceração ${ }^{3}$, ambos com etanol absoluto $(99,5 \%)$. Os extratos obtidos foram caracterizados quanto ao $\mathrm{pH}$, concentração de fenóis totais e de antocianinas, sendo posteriormente submetidos a estudo de estabilidade em diferentes condições de armazenamento.

\section{Resultados e Discussão}

Para os testes de extração foram utilizadas as castanhas com cascas e sem cascas, e apenas as cascas. A maior concentração de fenóis totais e de antocianinas foram obtidas pela maceração das castanhas com casca. Esse extrato também demonstrou o melhor comportamento durante os estudos de estabilidade (Figura 1). Os valores de $\mathrm{pH}$ também não sofreram variações significativas, permanecendo na faixa de 5,5, extraídas por Soxhlet ou Maceração e em todas as condições de estudo.

O óleo comercial apresentou maior concentração de antocianinas e de fenóis totais do que os outros extratos (Figura 2).

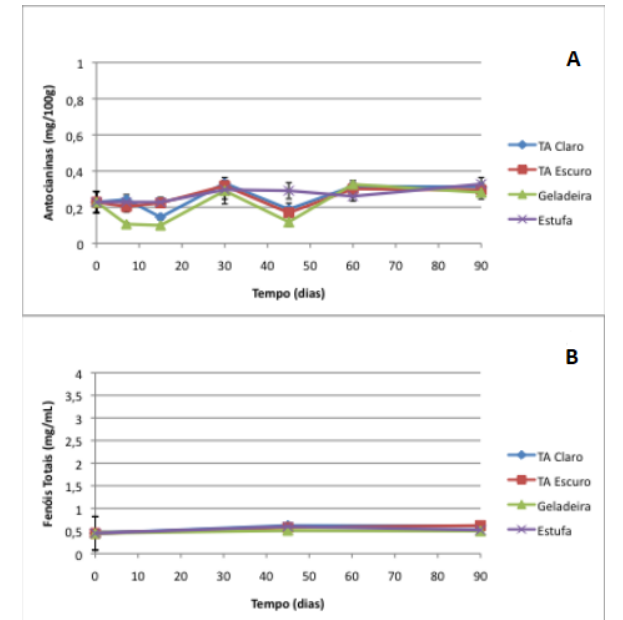

Figura 1. Concentração de antocianinas (A) e de fenóis (B) do extrato de castanha com casca obtidos por Maceração.
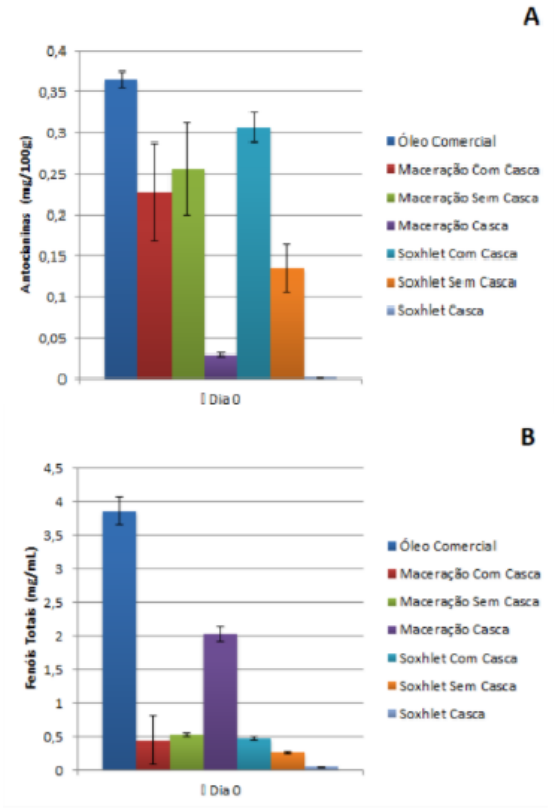

Figura 2. Comparação da concentração de antocianinas (A) e fenóis totais (B) do óleo comercial de castanha de baru com os extratos alcoólicos.

\section{Conclusões}

As concentrações de antocianinas e compostos fenólicos das amostras obtidas por maceração foram maiores, destacando-se o resultado da castanha com casca, o que justificou a sua escolha como o melhor extrato. $O$ óleo comercial apresentou maiores concentrações de fenóis totais e de antocianinas, o que pode ser atribuído ao seu método de obtenção, a prensagem à frio, já que não envolve a utilização de solventes ou aquecimento.

\section{Agradecimentos}

Faculdade de Ciências Farmacêuticas e Faculdade de Engenharia Química da Unicamp. Ao programa CNPq/PIBIC pelo financiamento do projeto.

\footnotetext{
${ }^{1}$ Takemoto, E. et al. Composição química da semente e do óleo de baru (Dipteryx alata Vog.) nativo do Município de Pirenópolis, Estado de Goiás. Rev. Inst. Adolfo Lutz, 60(2): 113 - 117, 2001.

${ }^{2}$ Andrade, P. M. M., CARMO, M.G.T. Ácidos graxos n-3: um link entre eicosanóides, inflamação e imunidade. MN - metabolic, v. 8, n. 3, p. 32 - 35, 2006.

${ }^{3}$ Simões, C.M.O.; Schenkel, E.P.; Gosmann, G.; Mello, J.C.P. D.; Mentz, L.A.; Petrovick, P. R. Farmacognosia - da planta ao medicamento. Ed. UFRGS, Porto Alegre, 5a ed, 2003.
} 